\title{
PERKEMBANGAN TEKNOLOGI DALAM INDUSTRI MEDIA
}

\author{
MUSLIMIN M. \\ Jurusan Ilmu Komunikasi Fakultas Ilmu Sosial dan Politik, Universitas Muhammadiyah Malang \\ E-mail: machmudmus@gmail.com
}

\begin{abstract}
ABSTRAK
Globalisasi yang terjadi saat ini, berdampak pada semua aspek kehidupan manusia, termasuk bagaimana manusia memperoleh dan menyampaikan informasi. Ketika dunia menjadi kosmopolitan, sehingga tercipta keseragaman budaya yang membuat komunikasi manusia saling mempengaruhi meskipun tempat itu sangat jauh. Salah satu tuntutan globalisasi adalah informasi dapat diakses oleh seluruh masyarakat. Dengan demikian, industri media yang ada harus dapat memenuhi permintaan itu. Salah satu upaya yang perlu dilakukan oleh industri media adalah membuat penyesuaian untuk kemajuan teknologi yang ada. Globalisasi informasi yang dimainkan oleh industri media telah menempatkan negara-negara berkembang sebagai bagian dari masyarakat informasi dunia yang mengharuskan dibentuknya peraturan dan penggunaan teknologi informasi di setiap negara dalam menanggapi perkembangan baik dalam tingkat regional dan internasional. Kegiatan penggunaan teknologi informasi harus dikembangkan tanpa mengorbankan hak-hak penonton dengan cara yang adil, sehingga pelanggaran yang berkaitan dengan penggunaan teknologi informasi dapat dihindari melalui penerapan prinsip-prinsip dan aturan seragam di setiap negara.
\end{abstract}

Kata kunci: perkembangan, teknologi, industri media

\begin{abstract}
Globalization is happening at the present time, have an impact on all aspects of human life, including how humans acquire and convey information. As the world becomes cosmopolitan, so as to create cultural uniformity that makes human communication affect each other even though the place is very far apart. One of the demands of globalization is the information accessible to the whole society. Thus, the existing media industry should be able to meet that demand. One effort that needs to be done by the media industry is to make the adjustments to the advancement of existing technology. The globalization of information that played by the media industry has put developing countries as a share of the world information society that requires the establishment of regulation and use of information technology in each country in response to developments in both regional and international levels. Activities use of information technology should be developed without compromising the rights of audience in a fair manner, so that the violations related to the use of information technology can be avoided through the application of uniform principles and rules in each country.
\end{abstract}

Key words: development, technology, media industry

\section{PENDAHULUAN}

Di awal perkembangan Ilmu komunikasi, media massa difahami sebagai alat penyampaian pesan melalui media, yang umpan balik ( feed back) bersifat tertunda, namun untuk saat ini proses komunikasi melalui media massapun umpan baliknya sudah dapat dilakukan seketika. Hal ini dapat ditemukan melalui acara interaktif di televisi, atau melalui media on-line. Ada beberapa perkembangan yang dapat dicermati berkait dengan kemunculan berbagai media baru dewasa ini, diantaranya perkembangan dalam medium komunikasi massa itu sendiri, perkembangan yang terkait dengan teknologi informasi dan komunikasi, dan perkembangan konvergensi teknologi yang dapat menyebabkan lahirnya berbagai jenis industri media baru, baik media cetak maupun elektronik. Telepon seluler atau HP (hand phone) yang sangat populer, pada awalnya hanyalah alat komunikasi pengganti telepon yang memiliki keunggulan dari segi mobilitas (praktis dan mudah dibawa ke mana-mana). Namun, HP jenis terbaru kini tidak cuma sekadar alat untuk berkomunikasi atau saling berkirim SMS (short message services), melainkan memiliki fungsi yang beraneka ragam. Mulai dari kalkulator, notepad (untuk membuat tulisan), membuat presentasi, melakukan transaksi perbankan, menggantikan peran komputer dalam rangka menjelajahi internet, mengirim dan menerima e-mail, menerima dan mengirim berita, bahkan menerima siaran televisi. Inilah merupakan bukti perkembangan teknologi dalam industri media yang perlu dicermati. Karena 
itu perkembangan teknologi dalam industri media merupakan tingkatan penggunaan teknologi yang dilakukan oleh industri media dalam menyampaiakan pesan komunikasi kepada khalayaknya.

Dari gambaran fenemona yang terjadi seperti yang dikemukakan di atas, muncul pertanyaan diantaranya, apakah pembagian jenis jurnalisme untuk media cetak, media elektronik, dan media online -seperti yang terjadi sekarang ini masih dapat atau masih perlu dipertahankan? bagaimana dengan perkembangan teknologi, dikaitkan dengan struktur, mekanisme, pola kerja dan kepemilikan dalam industri media. Bagaimana kuasa pemilik modal dalam mempengaruhi pekerja dalam industri media dan khalayak. Bagaimana kemajuan dalam industri media merancang penyampaian pesan, serta bagaimana jika dikaitkan dengan aspek budaya. Berbagai masalah inilah yang akan dibicarakan dalam tulisan ini.

Globalisasi yang ditandai dengan pergerakan bebas informasi, uang, tenaga kerja, produk budaya, produk barang dan jasa yang melintasi batas-batas tradisional negara, makin mendesak berbagai industri media untuk betul-betul bersifat kompetitif dan mempertimbangkan faktor untung rugi (cost-benefit). Jika industri media yang bersangkutan mau survive. Jadi, tidak semata-mata hanya mempertimbangkan nilai "jurnalisme murni." Beberapa industri media cetak pada tahun-tahun terakhir ini terlihat dengan jelas berupaya menghilangkan jarak antara newsroom atau bagian redaksi (editorial) dengan bagian bisnis atau usaha. Mereka sudah mematok tanggal atau hari tertentu untuk halaman khusus otomotif, teknologi informasi, pendidikan, dan sebagainya. Penentuan tanggal dan hari tersebut dikoordinasikan jauh-jauh hari, antara bagian redaksi dan bagian sales, marketing, dan periklanan.Tujuannya, supaya di halaman koran tersebut terjadi kombinasi content yang sesuai antara artikel/berita dengan iklan yang dipasang. Artikel-artikel yang bertopik otomotif misalnya, akan didampingi oleh iklan-iklan dengan topik yang sejenis. Seperti, iklan mobil, asuransi mobil, perangkat audio mobil, sepeda motor, ban, minyak pelumas, akumulator, dan sebagainya. Dari kondisi semacam perlu adanya penjelasan yang dapt mengurai berbagai pertanyaan yang muncul, sehingga diharapkan adanya saling pengertian dan pemahaman antara pihak pengelola media dan pihak pengguna media di dalam memenuhi keprluannya masing-masing.

\section{METODE}

Perencanaan penelitian dilakukan dengan bebrapa langkah, antara lain pemilihan persoalan, penentuan ruang lingkup, pemriksaan tulisantulisan yang bersangkutan, perumusan kerangka teoritis, penentuan konsep-konsep, perumusan hipotesa. Peneilitian ini merupakan penelitian yang bertujuan unutk merekontruksi realita yang terjadi secara sistematis dan objektif, dengan cara mengumpulkan, mengevaluasi, dan memverifikasi, serta mensistematiskan bukti-bukti untuk menegakkan fakta dan memperoleh kesimpulan yang kuat, dihubungkan dengan fakta yang ada pada masa sekarang dan proyeksi masa depan.

Penelitian ini tergantung pada dua data, yaitu data primer yang merupakan data yang secara langsung diperoleh oleh peneliti dan sumber primer (data asli), dan data sekunder yaitu data yang diperoleh penelitian dari orang lain atau sumber sekunder jadi bukan asli. Dalam penelitian ini menghendaki kritik untuk memperoleh kualitas data, yakni kritik eksternal yang menanyakan apakah data itu autentik artinya datanya asli atau tiruan dan apabila autentik apakah relevan serta akurat. Selanjutnya adalah kritik internal, yaitu kritik yang menguji motif, objektifitas, dan kecermatan peneliti terhadap data yang diperoleh.

\section{HASIL DAN PEMBAHASAN}

Di awal milenium III ini, kalangan pakar teknologi komunikasi pada umumnya berpendapat bahwa akan terjadi pemekaran jenis-jenis industri media komunikasi massa, dan akibatnya akan muncul jenis-jenis industri media komunikasi massa baru yang sifatnya semakin canggih, volume pesanpesannya semakin besar dan kecepatannya kian tinggi. Hal ini menyebabkan sifat aktualitas dan kedekatan pesan-pesannya dengan pihak penerima di seluruh dunia (proximity) juga kian tinggi. Kedekatan tersebut juga sekaligus meliputi kedekatan geografis. Kedekatan sosiologis, kedekatan kultural, dan teksuk kedekatan psikologis antara pihak industri media dengan pihak khalayak (Muis, 2001).

Menurut Toffler dalam buku karangan Kumoroto dan Subandono (1998) menyebutkan bahwa peradaban yang pernah dan sedang dijalani oleh umat manusia terbagi tiga gelombang. Gelombang pertama adalah gelombang dimana tahapan manusia ditandai dengan peradaban agraris dan pemanfaatan energi terbarukan (8000 sebelum masehi - 1700). Gelombang kedua ditandai dengan munculnya revolusi industri (1700-1970-an). Dan gelombang terakhir adalah peradaban yang didukung dengan kemajuan teknologi informasi, pengolahan data, penerbangan, aplikasi luar angkasa, bioteknologi dan computer (lihat juga Sonny Yuliar dkk, 2001).

Berdasarkan realitas yang ada, sudah jelas bahwa kita berada pada gelombang ketiga, dimana kita hidup di zaman yang ditopang oleh kemajuan teknologi 
informasi yang memicu terjadinya ledakan informasi. Ledakan informasi yang terjadi membawa berubahan besar dalam kehidupan umat manusia. Kita telah mengalami masa peralihan dari masyarakat industri menjadi masyarakat informasi. Informasi saat ini menjadi bahagian penting dalam kehidupan manusia, baik itu individu maupun institusi. Informasi ikut berperan dalam menentukan keberhasilan seseorang dan institusi. Media baru yang bermunculan dan didukung oleh teknologi, akan menjadi bahagian yang sangat banyak menyajikan berbagai berita (Knight \& Alexis, 2009).

Sehubungan dengan fenemoena tersebut, maka ada sejumlah tren dalam industri media yang patut dicermati sebab dapat memberi peluang dan harapan ke depan, diantaranya; Aspek pertama, menyangkut perangkat keras (hardware) atau produk teknologi informasi dan komunikasi. Berbagai produk teknologi yang berkembang pesat akhir-akhir ini praktis telah menjelma menjadi medium-medium baru dalam penyampaian pesan. Aspek kedua, menyangkut pergeseran struktur dan mekanisme dalam industri media itu sendiri, yang mengakibatkan terjadinya perubahan dalam pola kerja dan operasional industri media. Pergeseran ini terjadi terutama karena didorong oleh faktor-faktor lingkungan global, seperti proses globalisasi, yang imbasnya mempengaruhi industri media (Flew, 2005).

Keseluruhan transformasi yang berlangsung dalam sektor industri media, pada hakekatnya mencerminkan suatu peralihan dari state regulation menuju market regulation, dimana operasional dari industri media tidak banyak lagi didasarkan atas intervensi negara, melainkan banyak ditentukan oleh mekanisme kekuatan pasar (Mosco, dalam Effendi dkk, 2003). Dalam konteks pengertian tersebut, pengurangan State regulation sebenarnya bukanlah "deregulasi" tetapi lebih tepat disebut sebagai ekspansi market regulation. Hanya saja perlu diketahui bahwa regulasi yang dijalnkan oleh negara dalam industri media, merupakan cikal bakal munculnya mekanisme kekuatan pasar untuk melakukan market regulation. Sebab market regulation muncul untuk menempatkan negara sebagai pihak yang akan menjamin keberlangsungan sistem tersebut.

Globalisasi pada intinya merupakan fenomena dimana dunia sebagai satu pasar global. Ciri-ciri pokok globalisasi adalah pergerakan bebas bagi gagasan, informasi, uang, tenaga kerja, pruduk budaya, produk barang dan jasa di tingkat global, makin tipisnya batas-batas teritorial antarnegara, serta terjadinya saling keterkaitan (interconnectedness) antara satu unsur dengan yang lain. Globalisasi terlihat dari masuknya dengan mudah berbagai program televisi asing, ataupun media cetak (surat kabar maupun majalah) untuk ditonton dan dibaca oleh publik yang berada di negara lain, dan untuk program televisi dapat dijumpai baik melalui saluran televisi siaran yang biasa, maupun melalui TV kabel. Bahkan Susanto (1993) secara tegas menyebutkan bahwa media massa termasuk televisi digolongkan sebagai "pusat globalisasi kedua" di suatu negara.

Indikasi lain dari globalisasi adalah masuknya modal asing dalam industri media nasional, seperti pembelian sebagian saham ANTV (Kasus di Indonesia) oleh Star TV, yang merupakan bagian dari imperium media News Corp (Rupert Murdoch). Sisi positif dengan munculnya fenomena seperti ini adalah industri media massa mengajak orang muda untuk berkarier pada sektor ini. Ada peluang kerja yang cukup menantang bagi orang-orang berbakat untuk maju bersama dalam mengembangkan diri secara profesional. Sejumlah saluran berita dalam bahasa Internasional, nasional dan daerah menawarkan berbagai kesempatan kerja untuk berbagai keahlian dalam bidang industri media massa. Dan realita yang muncul kemudian adalah wujudnya suatu kenyataan di mana peminat atau pencari kerja di bidang industri media komunikasi massa sangat tinggi.

Industri media sangat erat kaitannya dengan tumbuhnya semangat kapitalisme. Munculnya konglomerasi media, satu perusahaan besar menaungi beberapa media sekaligus seperti misalnya MNC dan Trans Corp, dianggap sebagai aktivitas pemusatan modal dalam industri media. Pertanyaan yang seringkali diajukan adalah apakah industri media memberi andil besar menyebarkan virus kapitalisme dalam urat kehidupan masyarakat. Atau justru semangat kapitalisme yang mengawali tumbuh suburnya industri media raksasa, di samping faktor regulasi. Tidak mudah menjawab pertanyaan tersebut, karena fenomena tersebut terjadi bukan di ruang hampa, bukan hanya permasalahan antara media dan kapitalisme saja. Tetapi juga melibatkan komponen lain dalam kehidupan sosial. Sehingga yang terjadi bukanlah sebuah proses linear melainkan kesalingterkaitan antarkomponen dalam sistem sosial yang jika divisualisasikan mungkin akan menjadi bentuk coretan semrawut.Namun bukan berarti kesemrawutan itu tidak bisa diuraikan. Dengan perspektif sosiologi media, kompleksitas hubungan multidimensi tersebut menemukan penjelasan yang masuk akal. Pendekatan yang digunakan dalam tulisan ini adalah pendekatan sosiologi makro dengan meminjam model hubungan media dengan dunia sosial yang ditawarkan oleh Croteau (2002) dalam bukunya Media/Society.Croteau menggambarkan 
peran media dalam kehidupan sosial dalam suatu model yang memiliki lima elemen pokok yaitu dunia sosial (social world), industri media, pesan dan atau produk media, pemirsa/audiens dan teknologi. Kelima elemen tersebut memiliki hubungan masing-masing dengan elemen lainnya baik langsung maupun tidak. Dunia sosial atau lingkungan terletak di tengah antara elemen lain yang menunjukkan posisinya sebagai pusat dari hubungan semua elemen. Untuk dapat memahami lebih jauh bagaimana model tersebut bekerja, terlebih dulu harus kita pahami peran media sebagai agen sosialisasi dan peran media dalam hubungan sosial. Ilustrasi berikut berupaya mengaplikasikan model Croteau.

Industri media yang dibangun dengan semangat kapitalisme tentu akan menghasilkan pesan atau produk media yang berorientasi pada bertambahnya modal. Bukti untuk produk media berorientasi modal adalah banyaknya iklan komersial dan besarnya pengaruh iklan dalam penentuan suatu program. Mungkin sebagian besar isi media tidak secara eksplisit menunjukkan keberpihakannya. Tetapi secara halus pesan-pesan kapitalisme yang menuntun pada perilaku konsumtif masyarakat disisipkan melalui tayangan sinetron, acara gosip, kuis berhadiah, polling SMS dan lain sebagainya. Selain pesan/produk media yang pro-kapitalisme, sebaliknya ada juga pesan media anti-kapitalisme yang nantinya akan diterima oleh audiens. Pesan anti-kapitalisme bisa berbentuk kritik atas pesan/ produk media kapitalisme atau praktek kapitalisme oleh media.

Kaitannya dengan institusi industri media, dan persoalan konglomerasi media sedikit banyak akan mempengaruhi kondisi manajemen pihak media baik itu yang terkait dengan cara maupun yang terkait dengan hasil kerja para pekerja media itu sendiri. Misalnya satu pesan/produk media, yang seharusnya hanya untuk ditayangkan oleh satu stasiun TV saja, bisa ditayangkan juga oleh stasiun TV lain yang masih dalam satu korporasi. Ibaratnya seorang pekerja yang bekerja untuk dua atau lebih perusahaan dengan menerima standar gaji satu perusahaan. Kondisi semacam ini jelas mempengaruhi cara kerja para pekerja media, terutama adanya keseragaman pesan, timbulnya persaingan tidak sehat antar pekerja bahkan berpotensi menjadi perbudakan pegawai media.

Pesan media, baik yang pro maupun yang antikapitalisme, pasti membawa dampak pada audiens meski dengan tingkatan yang berbeda-beda. Ada yang sebatas pada pengetahuan tentang pengertian dan praktek kapitalisme, ada yang sudah mengambil sikap terhadap kapitalisme dengan mendukung atau menolak, ada pula yang menjadi pelaku dalam bisnis kapitalisme, bahkan ada yang sudah terjerat masuk dalam lingkaran kapitalisme tapi tidak menyadarinya. Golongan yang terakhir adalah pihak yang sering kita sebut sebagai korban kapitalisme. Biasanya berasal dari golongan menengah ke bawah dengan ciri pola konsumsi tinggi. Perbedaan pengaruh tersebut wajar terjadi karena tiap individu memiliki kemampuan yang berbeda dalam memahami dan mengkonstruksi pesan. Mungkin saja untuk audiens mendapatkan informasi yang berlainan dengan pesan kapitalisme misalnya norma agama, sosial, adat budaya yang mengajarkan tentang hidup sederhana, hemat, kesetiakawanan.

Elemen yang juga tidak kalah pentingnya adalah teknologi, sebab menurut Robert M Maclever dan Charles H. Page dalam suatu artikel yang ditulis dengan judul Technology And Soscial Change (dalam Onong uchjana E: 2005) mengatakan bahwa setiap kemajuan teknologi, akan memungkinkan manusia mencapai hasil tertentu dengan usaha dan biaya yang minim, dan pada saat yang sama teknologi membantu mempercepat kerja manusia, termasuk dalam penyebarluasan pesan. Penyampaian pesan/ produk media penyiaran membutuhkan perangkat teknologi siaran yang canggih, sebab seiring dengan makin berkembangnya teknologi makin tinggi pula tingkat konsumsi masyarakat, termasuk dalam cara mendapatkan informasi. Jika sebelumnya teknologi TV identik dengan sebuah kotak berukuran besar dengan layar cembung di depan yang memerlukan antena di atas genteng sebagai penangkap gelombang siaran dan masih memerlukan aliran listrik untuk menyalakannya dan hanya dapat dinikmati siarannya jika listrik dan cuaca mendukung, maka perkembangan teknologi TV berikutnya semakin memanjakan pemirsa dalam menyajikan siarannya. Kini audiens berkesempatan untuk menikmati penyajian acara media penyiaran melalui beberapa teknologi penyiaran. Mulai dari TV layar datar yang memiliki kualitas audio-visual lebih baik dari sebelumnya, mobile TV (dari handphone dan mobil), TV kabel, internet dan TV digital sebagai tv masa depan

Teknologi komputer dan telekomunikasi berkembang terus dengan penemuan dan inovasi baru. Bahkan menurut Angela (2009) teknologi komunikasi telah masuk dan menjadi bahagian yang tak terpisahkan dari kehidupan manusia sehari-hari. Kecepatan prosesor komputer makin naik dan bandwidth jaringan makin tinggi. Bahkan setelah modem mencapai 9600 bps dan makin terus meningkat, maka aplikasi yang menggunakan jaringan ini mulai dapat menampilkan gambar statik. Saat ini tidak aneh jika sebuah situs web menampilkan animasi dengan menggunakan 
Flash yang membutuhkan bandwidth yang besar. Aplikasi yang membutuhkan pita yang lebar (highbandwidth applications) biasanya terkait dengan data dalam bentuk suara (audio) dan gambar bergerak (video). Aplikasi yang membutuhkan data seperti ini misalnya adalah video conferencing dan distance learning. Untuk di Indonesia, sayangnya, aplikasi yang akan menarik pengguna adalah aplikasi yang berhubungan dengan hiburan (entertainment). Download lagu MP3 secara resmi merupakan aplikasi yang langsung bisa diluncurkan di atas jaringan dengan kapasitas tinggi ini.

Dari berbagai kemajuan tersebut tentunya diharapkan lebih banyak aplikasi yang bersifat pendidikan. Berbagai materi kuliah di luar negeri telah tersedia dalam bentuk video yang dapat dilihat secara on-line (streaming). Sebagai contoh, kita dapat mengikuti kuliah "Computer Systems Colloqium" dari Stanford University di Amerika yang berisi presentasi berbagai pakar di bidang komputer dari situs kuliahnya di alamat web HYPERLINK "http:// www.stanford.edu/class/ee380/" http://www.stanford. edu/class/ee380/. Dengan demikian, kita tidak perlu pergi ke Amerika untuk mengikuti kuliah. Kuliah ditampilkan dalam bentuk koleksi video. Hanya saja kita tidak dapat mengikuti pelajaran ini jika akses ke Internet kita termasuk kategori lambat. Di kemudian hari tentunya akan semakin banyak materi pelajaran yang tersedia di Internet sehingga banyak mahasiswa dari berbagai negara dapat mengikuti kuliah tanpa perlu harus pergi jauh dari rumahnya.

Komunikasi melalui media massa merupakan industri besar dan bergengsi saat ini. Dalam industri komunikasi media massa di negara-negara maju telah mengalami transformasi yang sangat luas. Dalam konteks ini komunikasi massa merupakan istilah kolektif, yang memiliki serangkaian pengertian yang terkait langsung dengan konsep komunikasi media massa misalnya berita pembaca, pelaporan, kolumnis, radio joki, iklan, produksi, dan yang lainnya.

Trend peralatan dan media baru dalam proses komunikasi yang menjadi industri media yang sangat maju dewasa ini, menandai masyarakat yang bersandar pada inovasi teknologi yang bersifat spektakuler. Kondisi semacam ini dikenal dengan adanya sebuah terobosan dalam pemrosesan, penyimpanan dan transmisi informasi yang akhirnya membuka ruang bagi penerapan teknologi informasi melalui industri media, untuk berbagai aspek kehidupan masyarakat. Hal ini memungkinkan karena saat ini, dengan biaya yang relatif terjangkau (murah), orsng dapat menempatkan Komputer di dalam mesin ketik, mobil, alat pemasak, jam tangan, televisi dan bahkan mainan anak-anak (Sonny, 2001).
Saat ini ponsel misalnya tidak hanya digunakan untuk melakukan panggilan dan menerima panggilan serta mengirim dan menerima SMS (pesan), tapi bisa digunakan untuk berbagai kebutuhan lain. Salah satunya adalah untuk mengakses internet. Hal ini sangat menguntungkan bagi mereka yang memerlukan akses internet namun mempunyai mobilitas kerja diluar kantor bahkan diluar kota sekalipun. Pada dasarnya ada dua cara dimana ponsel dapat mengakses internet. Internet adalah bahagian terbaru dalam industri komunikasi massa. internet bahkan sampai saat sekarang ini dapat juga digunakan untuk menonton berita dan mendapatkan update terbaru pada kejadian saat ini dari seluruh dunia. Banyak orang beralih ke internet sebab dianggap dapat mempermudah orang untuk memperoleh nformsi tentang apa saja, atau sebaliknya membagi informasi kepada orang lain secara meluas dan tek terhingga, sebab internet dapat diakses di seluruh dunia seketika itu pula. Ini adalah alasan sekarang orang akan mengakses seluruh saluran berita dan surat kabar, bahkan banyak orang dengan tekun telah menjaga website mereka sendiri. Ini juga mengundang peluang kerja bagi jurnalis dan kolumnis untuk menempatkan artikel mereka, blog dan mengirimkan berita kepada jutaan orang di seluruh dunia.

Selain itu dengan saluran satelit, serangkaian saluran radio (FM) juga dapat diakses dengan mudahnya. Setiap kota metropolitan di dunia ini telah memiliki berbagai stasiun sendiri radio FM dimana para reporter radio handal bekerja. Media cetak juga telah membuat kemajuan luar biasa. Puluhan majalah, surat kabar internasional, nasional bahkan surat kabar daerah dengan mudah didapatkan ditempat-tempat lain (Jawa Pos dengan mudahnya didapatkan di Kuala Lumpur). Saat ini industri komunikasi massa tidak hanya terbatas pada batas suatu negara tertentu saja, tetapi telah menyebar dan telah mencapai tingkatan global. Kondisi ini menyebabkan sehingga setiap orang dengan mudahnya memperoleh berita tentang berbagai kejadian di belahan bumi yang lain yang sangat jauh dari tempat tinggal mereka. . Perkembangan lain dalam industri komunikasi massa adalah biro iklan. Sejumlah biro iklan besar dan kecil telah hadir di pasar global, sehingga fenemona ini juga sekaligus membuka kesempatan kerja kepada para peminat dibidang periklanan.

Sampai kuartal ketiga tahun 2006, di seluruh dunia sudah terdapat 100 juta pengguna HP (3G), dan 264 juta sambungan saluran pita lebar (fixed broadband line). Diperkirakan, aluran tetap ini akan mencapai 500 juta dalam beberapa tahun. Tercatat sudah lebih dari 120 operator ponsel seluruh dunia 
yang meluncurkan layanan TV bergerak, di mana lebih dari 90 persen mempergunakan jaringan seluler dua arah yang ada. Dari jaringan seluler ini ada lebih dari 2,5 miliar pengguna dengan teknologi unicast dan broadcast MBMS (multimedia broadcast multicast service). Artinya, dalam waktu yang tidak terlalu lama lagi, ketika kita bicara soal audience media televisi, audience itu sebetulnya tidak lagi terbatas pada pemilik pesawat televisi konvensional, tetapi juga mencakup pemilik HP (3G) dan pengguna komputer (yang juga bisa di-set untuk menerima siaran televisi).

Media yang semakin bersifat interaktif. Berkat perkembangan teknologi Internet, media lama seperti televisi juga bisa berubah sifat atau karakternya. Jika sebelumnya penonton televisi hanya dapat bersikap pasif, dalam arti hanya bisa "pasrah" memilih dari sekian channel yang tersedia, kini mereka bisa bersikap jauh lebih aktif. Secara teknologi kini sudah dimungkinkan munculnya IPTV (Internet protocol televisions) atau televisi Internet, yang teknologinya sudah dipamerkan di International Telecom Union World di Hong Kong, akhir tahun 2006. IPTV bisa berwujud siaran televisi biasa atau bank acara dan film yang dapat diakses penonton, mirip payTV di hotel-hotel berbintang. IPTV memiliki banyak keunggulan ketimbang televisi siaran konvensional, karena si penonton bisa sesuka hati memutar ulang siaran yang terlewatkan. Selain itu, IPTV juga bisa membuat siaran menjadi interaktif.

Sebagaimana teknologi lain yang berbasiskan Internet, kendali IPTV pun ada di tangan penonton. Komentar terhadap sebuah siaran bisa langsung dikirim ke stasiun televisi bersangkutan. Bahkan si penonton bisa berbagi komentar dengan para penonton lain, karena setiap IPTV memiliki nama (account) tersendiri. Sambil menonton siaran, mereka bisa saling berkomentar melalui pesan pendek yang muncul di layar televisi. IPTV bisa lebih personal, interaktif, HDTV (high definition television) atau TV yang memiliki ketajaman gambar yang sangat tinggi dan mengintegrasikan layanan komunikasi dan video. Selain membuka peluang distribusi dua arah dan multiple-stream, IPTV menjadi awal layanan triple play, atau satu saluran untuk tiga macam layanan (telepon suara, hiburan/TV, dan internet).

Teknologi IPTV ini sudah berkembang di Eropa dan Amerika, yang sudah memiliki infrastruktur komunikasi pita lebar. Di dua kawasan itu sudah empat juta rumah tangga tersambung dengan IPTV, dan diperkirakan pada tahun 2009 jumlah pelanggan akan meningkat cepat menjadi 36,8 juta. Di negara-negara berkembang termasuk di Indonesia hambatan bagi penyelenggaraan IPTV adalah belum tersedianya saluran komunikasi pita lebar yang memadai. Perlu investasi yang sangat besar, karena harus mengganti perangkat dan jaringan yang lama. Bagi para pemilik modal "industri media baru ini" menjadi peluang yang sangat menjanjikan Munculnya jenis "jurnalisme baru" Media internet sendiri, sebagai suatu media baru (new media), pada gilirannya juga telah menghadirkan sekian macam bentuk jurnalisme yang sebelumnya tidak kita kenal. Salah satunya adalah yang kita sebut sebagai "jurnalisme warga" (citizen journalism).

Dengan adanya media baru ini, akan muncul budaya baru pula, yakni budaya virtual yang merupakan hasil dari komunikasi virtual. Konsekwensinya adalah ruang-ruang sosial yang dapat kita lihat didunia nyata, dapat pula kita temukan dalam dunia virtual. Ruang-ruang sosial yang ada dalam dunia virtual merupakan simulasi sosial dari ruang nyata didunia, yang kemudian disebut sebagai ruang-ruang sosialcyberspace. Dikatakan demikian karena sudah jelas komunikasi bermedia komputer adalah komunikasi berjaringan, tanpa jaringan global ini kita tak dapat berkomunikasi dan menemukan karakteristik media sosial dengan jumlah peserta komunikasi yang tidak dapat dibatasi (lihat kasus Facebook). Dalam proses komunikasi melalui media baru, khususnya media sosial, terdapat tiga berbentuk komunikasi yang dapat kita lihat diantarana: 1) one-to-one communication, 2) one-to-many communicationdan 3) many-to many communication (Straubhar \& LaRose, 2002)

Inilah jenis baru dari komunikasi bermedia. Tidak dapat ditentukan apakah jenis komunikasi ini, menggambarkan jenis komunikasi ini bersifat sangat pribadi (interpersonal), sebab kondisinya tetap saja dapat dimodifikasi atau dimanipulasi dengan sengaja sesuai keinginan dengan adanya potensi interaksi. Inilah yang menjadikan virtual communication dianggap merupakan tipe hubungan komunikasi yang baru. Akibat dari perkembangan teknologi, terkadang definisi komunikasi yang dahulu difahami sepertinya terjadipergeseran makna.Bahkan banyak pakar yang menyatakan perlunya mendefinisikan ulang apa itu komunikasi, komunikasi antara personal, maupun komunikasi massa yang relevan dengan perkembangan dunia komunikasi sekarang.

Budaya virtual muncul karena media baru dan munculnya tipe hubungan komunikasi baru yaitu, komunikasi virtual. Kini manusia menyenangi berhubungan dan berkomunikasi dengan sesamanya secara virtual lewat media sosial yang mereka miliki (Jones, 1997). Dengan menggunakan teknologi yang ada kini seperi smart phone dan gadget lainnya, mereka akan dengan mudah menuliswall, message atau comment bahkan on-line di chat room, $k$ hanya sekedar untuk menghubungi temannya. Padahal mereka hanya sekedar janjian bertemu untuk jalan 
makan bersama saja, atau malahhanya sekedar ingin membagi cerita pribadinya di wall .

Sebenarnya media baru dalam dunia virtualnya menawarkan adanya ruang privat dan ruang publik. Namun semuanya diputuskan oleh individu sendiri (bersifat rational chice dan individual choice) sebagai pengguna apakah ingin menggunakan media baru ini untuk keprivatan identitasnya ataukah ia ingin benar-benar go public. Dalam ruang publik yang memang virtual bentuk komunikasi berlangsung secara argumentatif dan dialogis. Hal ini masih dalam bentuk komunikasi yang rasional. Oleh karena itu dalam media baru disediakan ruang public yang dapat dikatakan bebas. Setiap individu merasa merasa susah mengawasi dan diawasi atau di intervensi oleh siapapun termasuk pemerintah. Karena itulah individu dapat dengan mudah mengubah identitas atau membuat informasi tentang dirinya sesuai dengan keinginannya tanpa merasa bersalah atau disalahkan. Hampir tidak mungkin tiap pengguna mendapatkan intervensi dan pengaturan secara khusus dari pihak lain (Curran, 2006).

Menurtu Yasraf (2004) dalam ruang sosial ini individu dapat saja memiliki peran sosial yang berbeda-beda. Dalam hal ini pemahaman kita sendiri mengenai identitas mesti diperkuat. Karena kekaburan dari identitas ini maka batasbatas keidentitasan kitapun dapat dikatakan lenyap. Dengan demikian akan terjadi kekacauan persepsi mengenai identitas yang akhirny akan mempengaruhi gaya hidup, pikiran dan kepribadian seseorang. Jika identitas saja sudah kabur karena kebebasan penggunaannya maka dapat dikatakan identitas sendiri sudah hilang. Identitas yang dapat berubah-ubah seperti ini merupakan tanda hilangnya identitas. Karena ciri utama identitas adalah konsistensi.

Dalam cyberspace, dapat terjadi permainan identitas di dalamnya. Tiap pribadi dimungkinkan untuk memiliki identitas baru, identitas palsu, identitas ganda yang semuanya merupakan bahagian dari identitas budaya cyberspace. Bahkan individu yang memiliki identitas ganda dapat dikatakan telah membelah dirinya, membelah pribadinya. Bahkan perkembangan media baru dikenela dengan istilah "identitas online" yang dapat di buat oleh manusia di dalam dunia virtual. Identitas ini digunakan hanya ketika ia sedang dalam keadaan online dalam ruang cyber. Dalam dunia yang lain masih dimungkinakn ia memiliki identitas yang berbeda. Tidak adanya konsistensi ini salah satu bentuk hilangnya identitas diri manusia. Selain itu, dalam tingkat individu cyberspace dapat menimbulkan sifat ketergantungan. Khususnya adalah kecanduan dalam berkomunikasi di dunia cyber. Bukan hanya intensitas dalam berkomunikasi di cyberspace tapi juga frekuensinya.

Kondisi seperti yang telah dikemukakan di atas masih berada pada tataran tingkatan individu, terdapat tingkat selanjutnya yakni tingkat antar individu. Ruang sosial dunia nyata dapat kita cari bentuknya dalam dunia baru ini. Begitu pula dengan hubungan sosial dunia nyata juga dapat terjadi di alam maya. Pertemanan, persahabatan, pacar ataupun musuh dapat dilakukan di dunia cyber. Dengan demikian hal ini mengindikasikan adanya deteritorialisasi sosial, ketika hubungan - hubungan sosial tidak lagi membutuhkan ruang dan bentuk yang nyata (konvensional). Konsekuensinya adalah istilah "mendekatkan yang jauh dan menjauhkan yang dekat". Hasil penelitian yang dilakukan oleh Zeynep Cemalcilar, Toni Falbo, dan Laura M. Stapleton, menemukan bahwa peran teknologi komunikasi yang dimediasi oleh komputer (CMC) yang dilakukan di dunia cyber mempengaruhi pelajar-pelajar Internasional yang sedang belajar di Amerika Serikat. Pada tahap awal melalui CMC mereka sangat memelihara hubungan dengan negara asal mereka, terutama yang terkait dengan identitas rumah, dan persepsi dukungan sosial yang tersedia. Kondisi ini pada akhirnya mempengaruhi adaptasi psikologis, sosial-budaya, dan akademik mereka. Atau kata lain dengan CMC dapat mempengaruhi adaptasi seseorang terhadap budaya baru (Cemalcilar $\mathrm{dkk}, 2005)$

Tingkat terakhir yakni tingkat komunitas yang juga merupakan akumulasi dari tingkat sebelumnya. Bahkan cyberspace telah dapat menciptakan komunitas yang terbuka dan demokratik yang disebut komunitas imajiner. Berbeda dengan komunitas konvensional yang membutuhkan ruang dan waktu yang nyata. Komunitas imajiner tidak membutuhkan itu semua, ia hanya membutuhkan aliran bit-bit (data digital) dalam komputer.

Komunitas dalam cyberspace tidak sama dengan komunitas sebenarnya. Komunitas virtual memiliki perbedaan pada bentuk, struktur dan sistemnya dibandingkan dengan komunitas konvensional yang ada. Jika komunitas konvensional biasanya memiliki struktur kepemimpinan, struktur normatif seperti adat atau hukum, lembaga normatif seperti pengadilan yang memiliki mekanisme kontrol sosial. Maka dalam komunitas virtual kesemuanya hampir tidak ada. Karena setiap individu seakan-akan menjadi aktor-aktor yang lebi bebas sesuai peran yang dikehandakinya. 
Fakta menunjukkan bahwa kini seorang individu secara bebas telah dapat membuat informasi yang benar-benar baru mengenai dirinya di halamannya sendiri. Dengan demikian satu individu sudah dapat membuat identitas baru tentang dirinya kepada dunia baru juga. Identitas tersebut tentunya sulit untuk dibuktikan kenyataannya. Bisa saja semua informasi yang ia masukkan dalam akunnya adalah fiktif atau bisa juga fakta, tidak ada yang tahu kecuali jika kita memang mengenalnya secara dekat. Pada kondisi inilah peluang untuk melakukan "penipuan" atau "pembohongan" terbuka lebar. Bahkan sejalan dengan hal ini, hasil penelitian yang dilakukan oleh Bente Traeen, Toril Sorheim Nilsen dan Hein Stigum tentang penggunaan pornogarafi dalam media tradisional dan internet di Norwegia mengemukakan bahwa dari 10.000 orang Norwegia yang berusia antara 18-49 tahun, 84\% diantaranya telah melihat film-film porno melalui internet dan 34\% yang memeriksa situs-situs porno di internet. Dengan demikian dapat dinyatakan bahwa kemajuan teknologi dalam industri media, dapat memberi manfaat positif, tetapi juga tidak menutup kemungkinan berdampak negatif (Traeen dkk, 2006).

\section{SIMPULAN}

Berdasrkan penjelasan yang telah dikemukakan bahwa; perkembangan teknologi dalam industri media yang demikian pesat telah menyebabkan perubahan kegiatan kehidupan manusia dalam berbagai bidang yang secara langsung telah mempengaruhi lahirnya bentuk-media baru., maka kemajuan teknologi dalam industri media tersebut merubah 180 derajat keadaan di lapangan. Dengan biaya relatif murah, kini setiap pengguna Internet pada dasarnya bisa menciptakan media tersendiri. Mereka dapat melakukan semua fungsi jurnalistik sendiri, mulai dari merencanakan liputan, meliput, menuliskan hasil liputan, mengedit tulisan, memuat dan menyebarkannya di berbagai situs Internet atau di weblog yang tersedia gratis. Dengan demikian, praktis dapat dikatakan bahwa semua orang yang memiliki akses terhadap Internet bisa menjadi "jurnalis dadakan," meski tentu saja kualitas jurnalistik mereka masih bisa kita perdebatkan. Suka atau tidak, tren munculnya "jurnalisme warga" dan "jurnalis dadakan" semacam ini tampaknya makin kuat. Sebagai catatan, berita pertama soal bencana Tsunami di Aceh, pada Desember 2005 lalu, justru muncul dan diketahui publik melalui blog pribadi di Internet. Jadi, tidak melalui saluran-saluran media yang konvensional. Dengan demikian, kehadiran "jurnalisme warga" ini juga telah menjadi tantangan bagi jenis "jurnalisme mapan," yang diterapkan di media-media konvensional, seperti suratkabar, majalah, radio, dan televisi.

\section{DAFTAR PUSTAKA}

Angela, C.G., et al. 2009. Ethnographic Approaches to the Internet and Computer-Mediated Communication. Journal of Contemporary Ethnography.Volume 38 Number 1. February 2009 52-84.

Cemalcilar, Zeynep. 2005. Cyber Communication: A new Opportunity for International Students' Adaptation. International Journal of Intercultural Relations, Volume 29, Issue 1, January 2005, Pages 91-110.

Croteau, David. 2002. Media Society: Industries, Image, and Audiences (third edition). USA. Pine Forge Press.

Curran, James. 2006. Media and Cultural Theory. New York : Routlegde.

Effendi Gazali et al. 2003. Konstruksi Sosial Industri Penyiaran: plus Acuan tentang Penyiaran Publik \& kumunitas. Jakarta. Departemen Ilmu komunikasi FISIP UI.

Flew, T. 2005. New Media An Introduction $2^{\text {nd }}$ Edition. UK: Oxford

Jones, Steve. 1997. Virtual Culture: Introduction. London: Sage Publication.

Knight, J. \& Alexis, Weedon. 2009. Additional services and information for Convergence. The International Journal of Research into New Media Technologies. London, Los Angeles, New Delhi and Singapore Vol 15(1): 5-7.

Kumorotomo, W. dan Subandono, A.M. 1998. Sistem Informasi Manajemen dalam Organisasi Publik. Yogyakarta; Gadjah Mada University Press

Muis, Andi. 2001. Indonesia di Era Dunia Maya: Teknologi Informasi dalam Dunia Tanpa Batas. Bandung. Rosda Karya.

Onong, U.E. 2005. Komunikasi \& Modernisasi. Bandung. CV. Mandar Maju.

Straubhaar, Joseph \& Robert, LaRose. 2002. Media Now - Communications Media in the Information Age. Third Edition. Belmont: Wadsworth.

Susanto, A.S., Sunario. 1993. Globalisasi dan Komunikasi. Jakarta. Pustaka Sinar harapan

Traeen, Bente et al. 2006. Use of Pornography in Traditional Media and on the Internet in Norway. The Journal of Sex Research. Volume 43, Nomor 3 August 2006: pp. 245-254.

Yasraf, A.P., 2004. Posrealitas: Realitas Kebudayaan dalam Era Posmetafisika. Yogyakarta: Jalasutra.

Yuliar, S. dkk. 2001. Memotret Telematika Indonesia Menyongsong Masyarakat Informasi Nusantara. Bandung. Pustaka Hidayah. 


\section{LEMBAR \\ HASIL PENILAIAN SEJAWAT SEBIDANG ATAU PEER REVIEW KARYA ILMIH : JURNAL LMIAH}

Judul Makalah

Penulis Makalah

Identitas Makalah
: Perkembangan Teknologi Dalam Industri Media : Mandiri
a. Nama Jurnal
: Jumal Teknik Industri
b. Nomor / Volum
c. Edisi (bulan/Tahun)
: Februarì 2011
d. Penerbit
e. Jumlah Halaman
: Dr. Muslimin, M.Si. : Hal. 59-65 .... Halaman

: ISSN: 1978-1431 Volume 12, Nomor 1

Kategori Publikasi Makalah

(beri $\sqrt{ }$ pada kategori yang tepat)

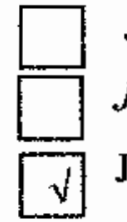

Jurnal Ilmiah Internasional

Jurnal Ilmiah Nasional Terakreditasi

Jurnla IImiah Nasional Tidak Terakreditasi

Hasil Penilaian Peer Review :

\begin{tabular}{|c|c|c|c|c|c|c|}
\hline \multirow{2}{*}{$\begin{array}{l}\text { Komponen } \\
\text { Yang Dinilai }\end{array}$} & \multicolumn{3}{|c|}{ Nilai Maksimal Jurnal Imiah } & \multicolumn{3}{|c|}{ Nilai Akhir Yang Diperoleh } \\
\hline & Intemasional & $\begin{array}{l}\text { Nasional } \\
\text { Terakreditasi }\end{array}$ & $\begin{array}{l}\text { Nasional } \\
\text { Tidak }\end{array}$ & $\begin{array}{c}\text { Peer } \\
\text { Review } 1\end{array}$ & $\begin{array}{c}\text { Peer } \\
\text { Review } 2\end{array}$ & Akhir \\
\hline $\begin{array}{l}\text { a. Kelengkapan Unsur Isi Buku } \\
(10 \%)\end{array}$ & & & 1 & & & / \\
\hline $\begin{array}{l}\text { b. Ruang Lingkup dan } \\
\text { Kedalaman Pembahasan (30\%) }\end{array}$ & & & 3 & & & 3 \\
\hline $\begin{array}{l}\text { c. Kecukupan dan } \\
\text { Kemuktahiran data/Informasi } \\
\text { dan Metodologi }(30 \%)\end{array}$ & & & 3 & & & 3 \\
\hline $\begin{array}{l}\text { d. Kelengkapan Unsur dan } \\
\text { Kualitas Penerbit }(30 \%)\end{array}$ & & & 3 & & & 3 \\
\hline Total $=(100 \%)$ & & & 10 & & & 10 \\
\hline
\end{tabular}

Malang, 2 Januari 2016

Peer Review 2

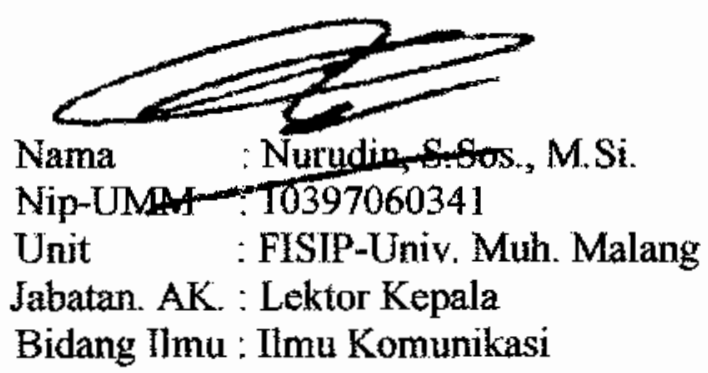




\section{LEMBAR \\ HASIL PENILAIAN SEJAWAT SEBIDANG ATAU PEER REVIEW KARYA ILMIAH : JURNAL LMIAH}

Judul Makalah

Penulis Makalah

Identitas Makalah

\section{: Perkembangan Teknologi Dalam Industri Media} : Mandiri
a. Nama Jurnal
b. Nomor/Volum
c. Edisi (bulan/Tahun)
d. Penerbit
e. Jumlah Halaman

: Jumal Teknik Industri

: ISSN: 1978-1431 Volume 12, Nomor 1

: Februari 2011

: Dr. Muslimin, M.Si.

: Hal. 59-65 .... Halaman

Kategori Publikasi Makalah :

(beri $\sqrt{ }$ pada kategori yang tepat)

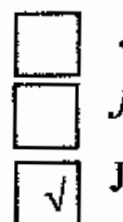

Jurnal IImiah Internasional

Jurnal Ilmiah Nasional Terakreditasi

Jurnla Imiah Nasional Tidak Terakreditasi

Hasil Penilaian Peer Review:

\begin{tabular}{|c|c|c|c|c|c|c|}
\hline \multirow{2}{*}{$\begin{array}{l}\text { Komponen } \\
\text { Yang Dinilai }\end{array}$} & \multicolumn{3}{|c|}{ Nilai Maksimal Jurnal Ilmiah } & \multicolumn{3}{|c|}{ Nilai Akhir Yang Diperoleh } \\
\hline & Internasional & $\begin{array}{c}\text { Nasional } \\
\text { Terakreditasi }\end{array}$ & $\begin{array}{l}\text { Nasional } \\
\text { Tidak }\end{array}$ & $\begin{array}{c}\text { Peer } \\
\text { Review } 1\end{array}$ & $\begin{array}{c}\text { Peer } \\
\text { Review } 2\end{array}$ & Akhir \\
\hline $\begin{array}{l}\text { a. Kelengkapan Unsur Isi Buku } \\
(10 \%)\end{array}$ & & & 1 & & & $l$ \\
\hline $\begin{array}{l}\text { b. Ruang Lingkup dan } \\
\text { Kedalaman Pembahasan }(30 \%)\end{array}$ & & & 3 & & & 3 \\
\hline $\begin{array}{l}\text { c. Kecukupan dan } \\
\text { Kemuktahiran data/Informasi } \\
\text { dan Metodologi }(30 \%)\end{array}$ & & & $\overline{3}$ & & & 3 \\
\hline $\begin{array}{l}\text { d. Kelengkapan Unsur dan } \\
\text { Kualitas Penerbit }(30 \%)\end{array}$ & & & 3 & & & 3 \\
\hline Total $=(100 \%)$ & & & 10 & & & 10 \\
\hline
\end{tabular}

Malang, 2 Januari 2016

Peer Review 1

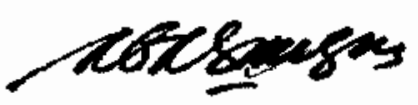
Nama
: Drs. Abdullah Masmuh, M.Si
Nip-UMM
10393090297
Unit
: FISIP-Univ. Muh. Malang
Jabatan. AK. : Lektor Kepala
Bidang Ilmu : Ilmu Komunikasi 